\title{
SEVEN YEARS EXPERIENCE WITH HYBRID TOMATOES
}

\author{
J. M. ANDEWEG and J. H. RUYTEN \\ Institute of Horticultural Plant Breeding, Wageningen \\ Received 25 Febr. 1957
}

\section{INTRODUCTION}

Many papers have already been published on experiences with tomato hybrids. Most of these papers describe the results obtained with outdoor hybrids. A much smaller number of them relate to glasshouse hybrids $(4,5,6,7$ and 9$)$.

In the literature one or more of the following advantages of hybrids over normal commercial varieties are mentioned:

a. stronger vegetative development,

$b$. higher yielding capacity,

c. higher early yield.

Production of $F_{1}$ seed on a commercial scale is possible because the crosses can be easily carried out and much seed is produced per cross. Moreover good breeder's protection is obtained by keeping the parents secret. Since 1942 the Dutch seed grower J. Bruinsma, Naaldwijk, has been successfully producing tomato hybrids. Among these hybrids, which are also grown outside the Netherlands, are Single Cross, Unic, Gouden Ster (Star), Export Wonder and Syston Cross.

In other countries, too, hybrid tomato seed is produced commercially, e.g. in England, Sweden, U.S.A., Canada, Bulgary and Japan. For outdoor tomatoes the price of hybrid seed may be a disadvantage, but for glasshouse tomatoes the higher price per plant is unimportant. On the basis of the 1957 seed prices in the Netherlands, a plant of a commercial variety costs about $\frac{1}{2}$ Dutch cent and a hybrid $\frac{3}{4}-1$ cent.

In order to find good hybrids for glasshouse culture in the Netherlands, a total of $196 \mathrm{~F}_{1}$ combinations was tested at the Institute of Horticultural Plant Breeding, Wageningen, from 1950 to 1956 inclusive. The results of the experiments are given in this paper. Since in these experiments the estimation of the cultural value relates to Dutch conditions, a short description of the latter is provided.

\section{THE GROWING AND MARKETING OF TOMATOES IN THE NETHERLANDS}

In the Netherlands tomatoes are grown almost entirely under glass. In 1956, 748 ha were grown in heated glasshouses and 1,154 ha in coldhouses. The total production for that year was estimated by the "Centraal Bureau voor de Tuinbouwveilingen", the Netherlands, at $123,000,000 \mathrm{~kg}$, of which about $80 \%$ was exported. The main importing countries were Germany and England, followed by Belgium, Sweden and Ireland. The fruits are picked ripe but in such a condition that they can travel well. They are destined for fresh consumption. The supply from heated glasshouses is from the end of April until the end of July, that from coldhouses begins at about the end of June and mostly ends in mid-September; some later cultures grown with additional heating end in November. 
Fig. 1. A good strain of allsa craig

Figure 7 on page 35 gives a survey of the fluctuation in the supply and average price for the years 1954, 1955 and 1956. The prices in late July and August are influenced by the quantity and quality of the outdoor crop in South Germany and Italy. A bad outdoor crop, due to bad summer weather in these countries, has a favourable effect on the prices in the Netherlands.

The plants are grown with a single stem and stopped after six to eight trusses have formed. The growing conditions are kept as favourable as possible, e.g. by regular soil disinfection. Good strains of Moneymaker and Ailsa Craig (Fig. 1) are the most widely used. For a survey of Dutch-grown commercial varieties and strains see the Descriptive List of Vegetables of the Institute of Horticultural Plant Breeding, Wageningen.

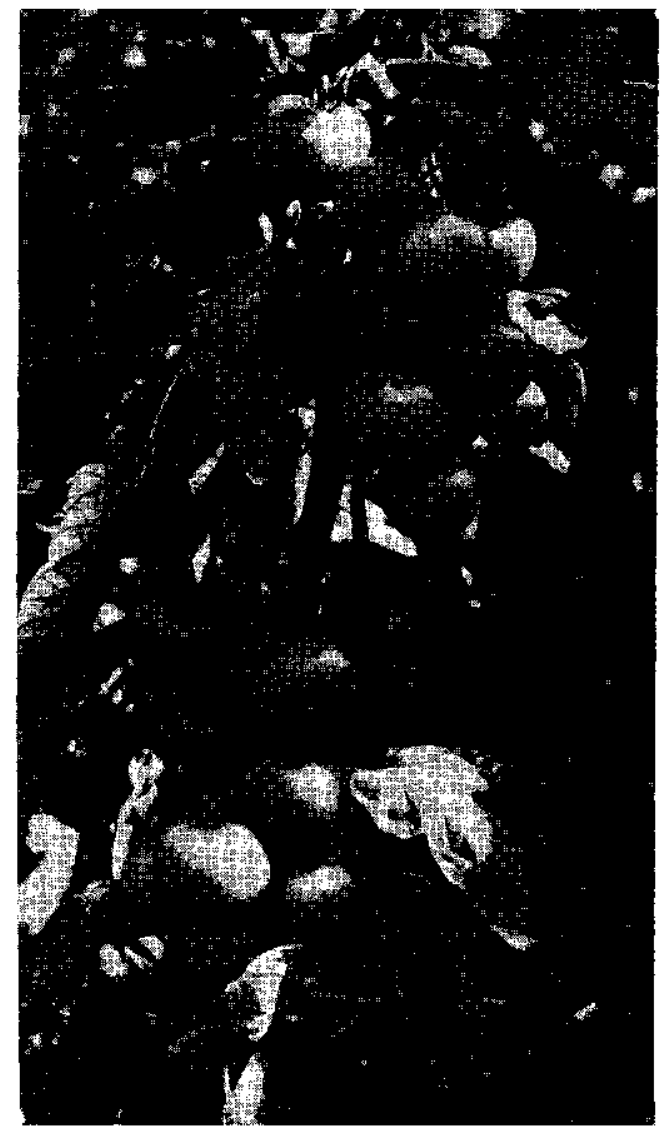

\section{EXPERIMENTAL DESIGN}

In 1949 and subsequent years a number of crosses were made which were judged in a coldhouse the following year. The plants were grown with a single stem and mostly stopped after six trusses had formed.

The available space under glass was insufficient to carry out replicated yield trials due to the large number of hybrids. Although it was possible to carry them out in the open, this was not done, mainly because of the fact that the hybrids had to be suitable for culture under glass and consequently also had to be judged under glasshouse conditions. Moreover the authors know from their own experiences and from the literature (8) that the results of varieties and $F_{1}$-hybrids grown under glass or out-of-doors do not always agree with each other.

However, data regarding the yield of the good $F_{1}$ hybrids were collected (total yield, total number of fruits, average fruit weight). Owing to the small number of plants these data can only be regarded as of an informative nature. The hybrids were generally grown in single rows of 12 plants, judged for their suitability for culture under glass and compared with their parents and commercial varieties. Ratings were given for earliness, fruit characters, productivity and disease resistance. The $F_{1}$-hybrids having 
irregularly shaped and/or too large fruits, or other fruit defects, or maturing too late, were discarded after one year. The other $F_{1}$ hybrids were grown again the following year, together with new $F_{1}$ hybrids. Thus all worthless and inferior $F_{1}$ 's were gradually eliminated, while the moderately good and good hybrids were maintained in our experiments for a number of years.

In judging the hybrids we had the following ideal tomato in mind: it should be suitable for growing under glass in the Netherlands; set fruit easily, even under less favourable conditions; give fruits preferably weighing $65-85$ grams each, which should be entirely round, not ribbed, without irregular scars, a good uniform colour both internally and externally, not liable to fruit defects such as green back and blotchy ripening, and sufficiently firm for transport. It should ripe early and preferably be resistant to the most important diseases.

\section{RESULTS}

Table 1 shows the estimation of the cultural value of eleven hybrids, which proved suitable for glasshouse culture in the Netherlands.

TABLE 1. TOMATO HYBRIDS SUTTABLE FOR GLASSHOUSE CULTURE IN THE NETHERLANDS

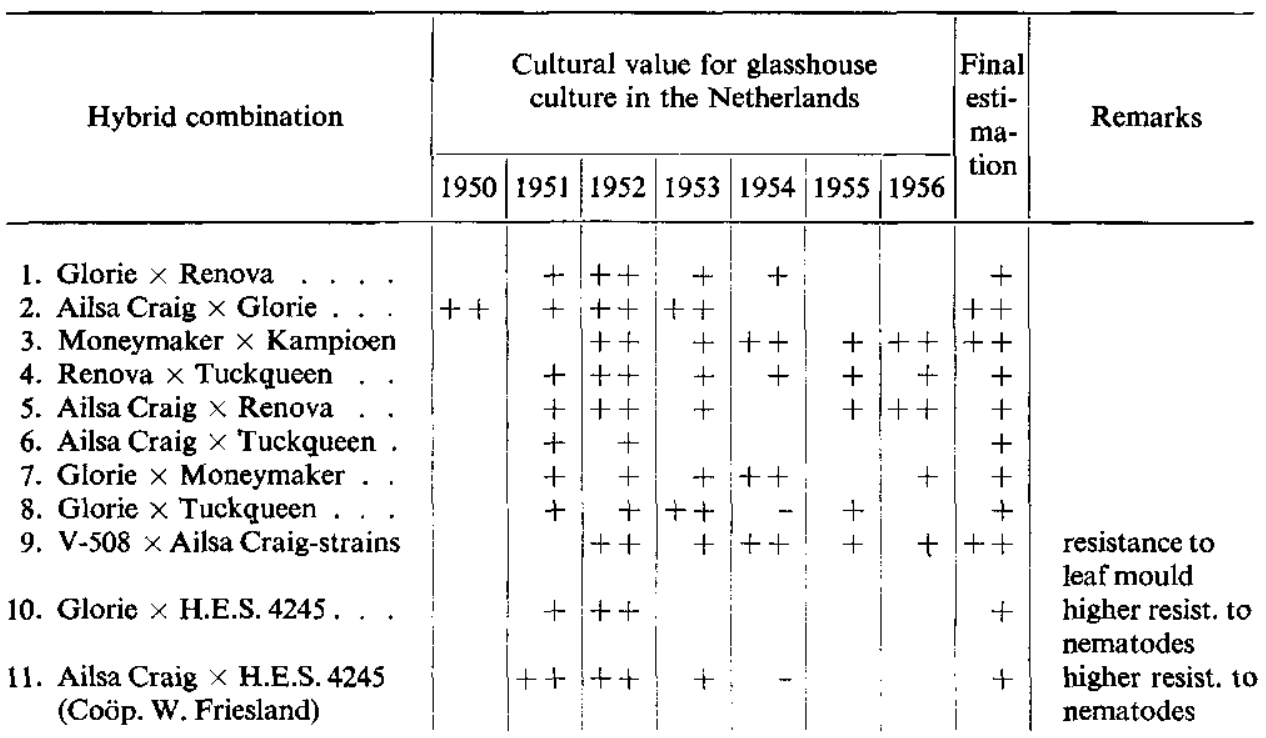

If the growth of the plants is too rank the fruits of the numbers $1,4,5,6,7$ and 8 are more liable to quality defects than those of the numbers 2,3,9 and the good strains of Moneymaker and Ailsa Craig.

Legend.

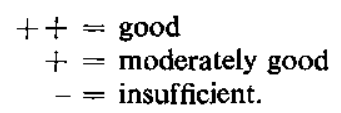


Table 2 presents the yield data of these eleven hybrids.

For completeness Table 3 gives a survey of all other estimated hybrids, which proved unsuitable for glasshouse culture in the Netherlands.

Table 2. Yield Data Of EleVEN TOMATO HYBRIDS AND THEIR PARENTS

\begin{tabular}{|c|c|c|c|c|c|c|c|c|c|c|c|c|c|c|c|c|c|c|c|c|}
\hline & \multicolumn{6}{|c|}{ Yield per pl. in $\mathrm{kg}$} & \multicolumn{7}{|c|}{$\begin{array}{l}\text { Number of fruits } \\
\text { per pl. }\end{array}$} & \multicolumn{6}{|c|}{$\begin{array}{l}\text { Average fruit } \\
\text { weight in } \mathrm{gr}\end{array}$} \\
\hline & & 51 & '52 & 53 & '54 & '55 & '56 & '51 & '52 & '53 & '54 & 4 & & $\left.56\right|^{\prime}:$ & '51]' & 52 & '53 & 54 & 55 & 56 \\
\hline Glorie . . . . . . . & & & 2.3 & 3.3 & 3.7 & & & & 34 & 47 & 52 & 2 & & & & 70 & 69 & 72 & & \\
\hline Renova . . . . . . & & & 2.5 & 2.9 & 3.6 & & & & 26 & 31 & 36 & 6 & & & & 95 & 93 & 100 & & \\
\hline Glorie $\times$ Renova & & & 2.8 & 3.7 & 4.6 & & & & 37 & 52 & 55 & 5 & & & & 75 & 71 & 84 & & \\
\hline Ailsa Craig . . . . & & 3.0 & 2.1 & 2.8 & & & & 51 & 32 & 47 & & & & & 59 & 67 & 61 & & & \\
\hline Glorie . . . . . . . & . & 3.7 & 2.3 & 3.3 & & & & 56 & 34 & 47 & & & & & 66 & 70 & 69 & & & \\
\hline Ailsa Craig $\times$ Glorie & . & 4.2 & 2.3 & 3.5 & & & & 64 & 36 & 54 & & & & & 65 & 64 & 65 & & & \\
\hline Moneymaker . . . . & . & & & 3.1 & 3.9 & 3.1 & 2.8 & & & 41 & 48 & 8 & 34 & 37 & & & 77 & 81 & 90 & 76 \\
\hline Kampioen . . . . & . & & & 2.4 & 4.4 & 2.8 & 2.8 & & & 44 & 59 & 9 & 43 & 38 & & & 55 & 74 & 64 & 74 \\
\hline Moneym. $\times$ Kampioen & & & & 3.4 & 3.9 & 3.5 & 3.2 & & & 56 & 53 & 3 & 58 & 49 & & & 62 & 74 & 60 & 65 \\
\hline Renova ...... & . & & 2.5 & 2.9 & 3.6 & 3.7 & & & 26 & 31 & 37 & 7 & 37 & & & 95 & 93 & 100 & 97 & \\
\hline Tuckqueen . . . . . & . & & 2.2 & 3.0 & 3.8 & 3.6 & & & 30 & 31 & 37 & 7 & 32 & & & 76 & 97 & 106 & 111 & \\
\hline Renova $\times$ Tuckqueen & . & & 2.6 & 4.0 & 4.4 & 3.7 & & & 34 & 46 & 44 & 4 & 40 & & & 77 & 87 & 100 & 90 & \\
\hline Ailsa Craig . . . . . & . & & 2.1 & 2.8 & & 3.1 & & & 32 & 47 & & & 51 & & & 67 & 61 & & 61 & \\
\hline Renova ....... & . & & 2.5 & 2.9 & & 3.7 & & & 26 & 31 & & & 37 & & & 95 & 93 & & 97 & \\
\hline Ailsa Craig $\times$ Renova & . & & 1.9 & 3.7 & & 3.6 & & & 30 & 54 & & & 44 & & & 64 & 68 & & 82 & \\
\hline Ailsa Craig . . . . . & . & 3.0 & 2.1 & & & & & 51 & 32 & & & & & & 59 & 67 & & & & \\
\hline Tuckqueen . . . . . & . & 4.2 & 2.2 & & & & & 53 & 30 & & & & & & 79 & 76 & & & & \\
\hline Ailsa $\mathrm{Cr} . \times$ Tuckqueen & . & 4.7 & 2.3 & & & & & 65 & 35 & & & & & & 73 & 66 & & & & \\
\hline Glorie . . . . . . . & . & & 2.3 & 3.3 & 3.7 & & 3.2 & & 34 & 47 & 52 & 2 & & 47 & & 70 & 69 & 72 & & 69 \\
\hline Moneymaker . . . . & . & & 2.5 & 3.1 & 3.9 & & 2.8 & & 40 & 41 & 48 & 8 & & 37 & & 64 & 77 & 81 & & 76 \\
\hline Glorie $\times$ Moneymaker & . & & 2.3 & 3.9 & 4.7 & & $3 .($ & & 36 & 55 & $5^{5}$ & 7 & & 44 & & 64 & 70 & 82 & & 68 \\
\hline Glorie & & & 2.3 & 3.3 & 3.7 & 73.2 & 3.2 & & 34 & 47 & 7.52 & 2 & 46 & 47 & & 70 & 69 & 72 & 68 & 69 \\
\hline Tuckqueen . . . . . & $\cdot$ & & 2.2 & 3.0 & 3.8 & 3.6 & 2.2 & & 30 & 31 & 3 & 7 & 32 & 30 & & 76 & 97 & 106 & 111 & 74 \\
\hline Glorie $\times$ Tuckqueen & . & & 2.1 & 4.6 & 5.0 & 3.9 & 2.8 & & 31 & 55 & 5 & 3 & 50 & 37 & & 68 & 77 & 95 & 79 & 74 \\
\hline V-508 (Vagebond) . . & • & & & 3.5 & 4.0 & 2.4 & & & & 38 & 37 & 7 & 31 & & & & 91 & 108 & 78 & \\
\hline Ailsa Craig . . . . . & $\cdot$ & & & 2.8 & 3.8 & 3.1 & & & & 47 & 5 & 7 & 51 & & & & 61 & 67 & 61 & \\
\hline V $508 \times$ Ailsa Craig & . & & & 4.0 & 3.7 & 74.9 & & & & 54 & 4 & \begin{tabular}{l|l}
4 & 5
\end{tabular} & 54 & & & & 74 & $\mid 85$ & 90 & \\
\hline Glorie . & & 3.7 & 2.3 & & & & & 56 & 34 & & & & & & 66 & 70 & & & & \\
\hline H.E.S. 4245 . . . . . & & 0.7 & 0.6 & & & & & 32 & 26 & & & & & & 22 & 24 & & & & \\
\hline Glorie $\times$ H.E.S. 4245 & & 4.7 & 2.9 & & & & & 72 & 45 & & & & & & 65 & 65 & & & & \\
\hline Ailsa Craig . . . . . & . & 3.0 & 2.1 & 2.8 & 2.3 & & & 51 & 32 & 247 & 5 & 77 & & & 59 & 67 & 61 & 67 & & \\
\hline H.E.S. 4245 . . . . . & & 0.7 & 0.6 & 0.7 & 7) & & & 32 & 26 & $62 t$ & & - & & & 22 & 24. & 28 & - & & \\
\hline Ailsa Cr. $\times$ H.E.S. 4245 & & 4.7 & 2.9 & 4.6 & 5 & & & 76 & 52 & 60 & & 2 & & & 62 & 56 & 75 & 75 & & \\
\hline
\end{tabular}




\section{J. M. ANDEWEG AND J. H. RUYTEN}

As already stated in the introduction, it appears from the literature that hybrids differ from normal commercial varieties by stronger vegetative development, higher yielding capacity and higher early yield.

TABle 3. TOMato hybrids UnSUTtable For GLASSHOUSE CULTURE IN THE NETHERLANDS

\begin{tabular}{|c|c|}
\hline Parent 1 & Parent 2 \\
\hline $\begin{array}{l}\text { Very early ripening } \\
\text { selftopper from } \\
(\text { T1 } 320 \times \text { (Farthest } \\
\text { North } \times \text { Valiant) })\end{array}$ & $\begin{array}{l}\text { Various Dutch and foreign varie- } \\
\text { ties }\end{array}$ \\
\hline Westlandia & $\begin{array}{l}\text { Renova, Tuckqueen, Tuckswood, } \\
\text { Sparks Earliana, Marglobe, Domi- } \\
\text { nant, Bruinsma JéBé, Glorie, Mo- } \\
\text { neymaker, Radio, Ailsa Craig, } \\
\text { H.E.S. } 4245\end{array}$ \\
\hline Bruinsma JéBé & $\begin{array}{l}\text { Various Dutch varieties and a } \\
\text { series of leafmould resistant lines } \\
\text { of E.A. Kerr }\end{array}$ \\
\hline $\begin{array}{l}\text { Vetomold, V } 121, \text { V } \\
473, \text { V } 4802 \text {, V } 4804\end{array}$ & Various Dutch varieties \\
\hline Stambovoy Alpatyev & $\begin{array}{l}\text { Renova, Westlandia, Ailsa Craig, } \\
\text { V 473, V 4802, V 4804, Money- } \\
\text { maker, Bruinsma JéBé, Glorie and } \\
\text { our own leafmold res. lines }\end{array}$ \\
\hline Tuckswood & $\begin{array}{l}\text { Kampioen, Glorie, Radio, Sparks } \\
\text { Earliana, Tuckqueen }\end{array}$ \\
\hline Sparks Earliana & $\begin{array}{l}\text { Ailsa Craig, Glorie, Moneymaker, } \\
\text { Renova, Tuckqueen and our own } \\
\text { leafmould res. lines }\end{array}$ \\
\hline Marglobe & $\begin{array}{l}\text { Ailsa Craig, Glorie, Moneymaker, } \\
\text { Renova, Dominant }\end{array}$ \\
\hline Renova & $\begin{array}{l}\text { V } 501 \text { to V } 508 \text { incl., F } 55, \text { F } 58 \text {, } \\
\text { F } 512, \text { F } 514, \text { F } 515, \text { B } 120, \text { V } 121\end{array}$ \\
\hline Meteor & $\begin{array}{l}\text { Moneymaker, and a few of our } \\
\text { own leafmould res. lines }\end{array}$ \\
\hline Earlinorth & $\begin{array}{l}\text { Ailsa Craig, Glorie, Econoom, } \\
\text { Moneymaker, Kessler, Robar, No. } \\
10-\text { Pannevis, Renova, Tuckqueen } \\
\text { and our own leafmould res. Iines }\end{array}$ \\
\hline Radio & Glorie \\
\hline
\end{tabular}

Principal drawbacks of $\mathbf{F}_{\mathbf{1}}$

Fruits too small and/or of undesirable shape. Worthless despite its earliness

Angular fruits, in many $F_{1}$ 's tending to become soft. Most of the hybrids ripened too late

Fruits mostly angular, ribbed, highly susceptible to yellow top

Insufficient resistance to leaf mould, also in other respects unsatisfactory

Fruit shape and firmness of ten unsatisfactory. Despite earliness worthless

Undesired fruit shape and/or strong tendency towards fruit defects

Fruit shape often poor. Trusses above 2 nd truss mostly very small.

Poor fruit shape

Late maturing, suffer much from green back

Poor fruit shape, liable to fruit defects

Often poor fruit shape, fruits mostly rather small, often soft. Spindly plants, higher trusses often insufficiently developed.

Very liable to fruit defects 
EXPERIENCE WITH HYBRID TOMATOES

\begin{tabular}{l|l|l}
\hline \multicolumn{1}{c|}{ Parent 1 } & \multicolumn{1}{c}{ Parent 2 } & Principal drawbacks of $F_{1}$ \\
\hline Moneymaker & Renova & Very liable to fruit defects \\
Moneymaker & Tuckqueen & ditto \\
Moneymaker & Sperl's Zukunft & ditto \\
Renova & v. d. Berg's Ailsa Craig & ditto \\
Tuckqueen ... & Houtbaai & ditto \\
V 504, V 505, V 506, & Glorie, Ailsa Craig, Coöp. W. & ditto \\
F 512, B 120 & Friesland, Abunda & ditto \\
H.E.S. 4245 & v.d. Berg's Ailsa Craig, Renova & ditto \\
H.E.S. 4434 & Moneymaker & insufficient resistance to leafmould \\
F 515 & Ailsa Craig-strains & fruits often rather small \\
Ailsa Craig, Coöp. & Moneymaker &
\end{tabular}

Now we will discuss our experimental results and compare them with the results mentioned in the literature.

\section{Stronger vegetative development}

All our hybrids, especially in their early stage of development, grew markedly stronger than normal varieties. This stronger growth remained visible later, except in crosses with Sparks Earliana and determinate bush varieties such as Earlinorth and Meteor. Hybrids with the last mentioned varieties made strong growth at first, but later on the plants became spindly, resulting in an insufficient development of the higher trusses.

Under unfavourable growing conditions the more vigorous growing hybrids may be expected to have better yielding possibilities than normal varieties. Increased vigour may be required for growing in pots, provided the growth can be fully controlled. The stronger vigorous growth may be disadvantageous if cultural conditions cause too rank growth. This may result in a lower fruit set, poor fruit shape and other fruit quality defects.

More vigorous growth in hybrids was also found by other research workers. It is evident that the useful effect of the higher vigour will be greatest in outdoor crops grown under less favourable conditions. WALKOF and NUTTALL moreover stated that hybrid tomatoes are more resistant to cold weather and recover more rapidly from physical damage than pure varieties.

\section{Higher yielding capacity}

Glasshouse tomatoes in the Netherlands are mostly stopped after six to eight trusses have formed. This limits of course the higher yielding capacity of the hybrids.

Table 2 shows the yield data of our best hybrids. In most cases the total yield of 
these hybrids proves to be higher than that of both parents, but sometimes these hybrids produce an almost equal yield to the most productive parent; in exceptional cases the yield of a hybrid is lower than that of both parents.

Mostly the total number of fruits per plant of our best hybrids was higher than that of both parents. As stated earlier in this article it was impossible to carry out replicated yield trials. Therefore it was impossible to determine the statistical reliability of differences in total yield and total number of fruits of each individual cross-combination. However, for our eleven best hybrids, it is fully justified to conclude that as a rule hybrids give a higher yield and a higher total number of fruits than their parents.

The average fruit weight is on the same level as that of the parents. This confirms the observations of ASHTON (2), who states that a higher yield of hybrids expresses itself in a larger number of fruits rather than an increased fruit size.

An increased number of fruits in hybrids may be the result of a higher number of flowers or of a better fruit set. Although we did not count the flowers we had the impression that in our experiments the fruit set of the hybrids was better than that of the commercial varieties.

\section{Earliness}

BURDICK (2) found that his hybrids generally produced the first ripe fruit earlier than the parents.

In our $F_{1}$ 's, obtained from Moneymaker $x$ the very early ripening determinate varieties Earlinorth and Meteor, the date on which the first ripe fruit was produced always occurred between that of the parents, with a tendency towards the earliest parent. Crosses between commercial varieties showing small differences in the dates on which the first ripe fruit is produced display the same tendency, but much less markedly.

However, the higher early yield of hybrids, as stated by several workers $(3,5,10)$, is much more important in practice. Figures 2, 3, 4, 5 and 6 show the incremental crop yields of some of our hybrids and their parents.

Figure 2 shows the typical incremental yield of a cross between the Dutch commercial variety Moneymaker and the early determinate variety Meteor. Moneymaker ripens latest, but gives the highest total yield; Meteor ripens earliest, has a short harvest period and gives a much lower total yield. The $F_{1}$ of these varieties does not give a higher total yield than Moneymaker, but produces most of its crop earlier in the season.

Figures 3, 4, 5 and 6 represent the incremental yield of crosses between commercial Dutch glasshouse varieties, compared with their parents. Although the differences in earliness between the parents are much smaller than in figure 2 , the hybrids always show a markedly higher early yield, sometimes combined with a considerably higher total yield. All the other $\mathrm{F}_{1}$-combinations presented in table 1 show the same behaviour.

\section{Rapid adaptation to changes in growing and marketing conditions}

Breeding a pure variety takes a long time. If suitable parents are available it is possible to introduce a hybrid with the desired commercial characters after one year's 

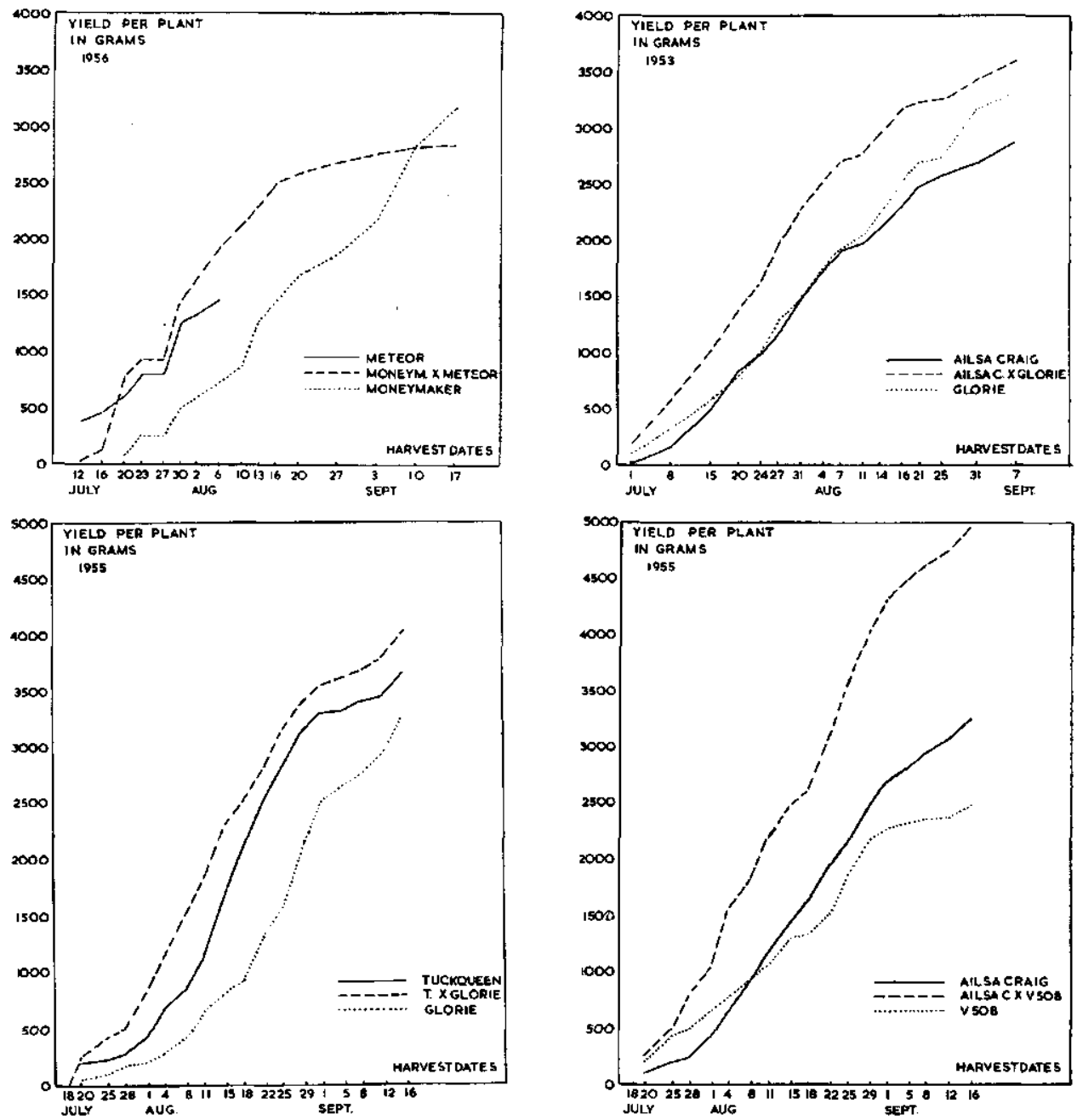

Figs. 2-5. Yield OF TOMATO HYBRIDS AND THEIR PARENTS

breeding work. This is exemplified by hybrids of which one of the parents possesses dominant factors for disease-resistance.

Crosses of Ailsa Craig strains with V 508 (Vagabond), bred by E. A. KERR of the Vineland Station Ontario, were fully resistant to leaf mould, and very acceptable from a commercial viewpoint. Crosses with V 507 gave similar results; crosses with V 502, V 503, F 55 and F 514 were slightly less acceptable.

Nematode resistant hybrids were obtained from crosses with H.E.S. 4245 of the Hawaii Experimental Station. We have not yet been able to confirm that the nematode resistance is fully dominant, mainly because H.E.S. 4245 was not yet homozygous. $F_{1}$ 's from H.E.S. $4245 \times$ Ailsa Craig and H.E.S. $4245 \times$ Glorie were highly productive for a number of years and also had good commercial characters. In 1954 however the Ailsa Craig $\times$ H.E.S. 4245 cross gave very poor results. Probably the plants were more 


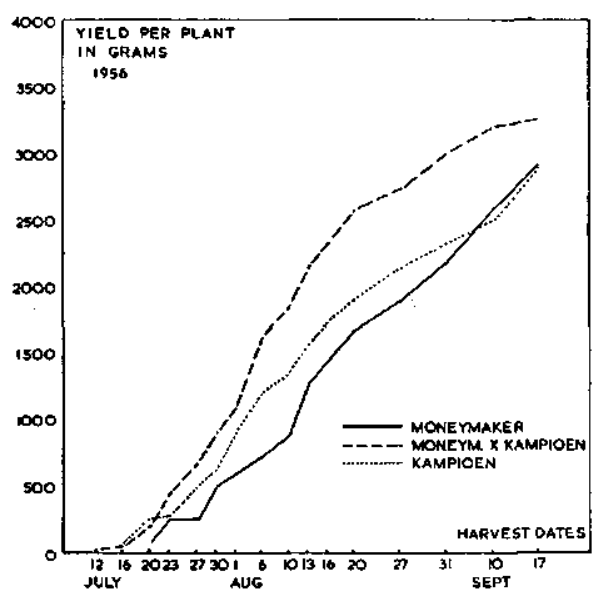

FIG. 6. YIELD OF THE TOMATO HYBRID MONEYMAKER $\times$ KAMPIOEN AND ITS PARENTS

susceptible to cold weather early in the growing season than plants of commercial varieties. Fruit setting was also very poor. Therefore care should be taken if parents originating from countries with a warmer climate are used in breeding. The susceptibility of H.E.S. 4245 to cold and wet weather was confirmed by an outdoor experiment in the bad summer of 1956, when H.E.S. 4245 did not set any fruit at all, and the plants were badly damaged. In the same year all crosses with several American outdoor varieties behaved similarly.

\section{Discussion}

After continuous selecting from a total of $196 \mathrm{~F}_{1}$ combinations eleven commercially acceptable hybrids were found. This shows that it is necessary to test a large number of combinations to find a small number of good hybrids. This confirms the experiences of others. For instance E. A. KERR (7) reports that at the Vineland Station, Ontario, a total number of 163 different $F_{1}$ combinations of glasshouse tomatoes has been tested since 1946 of which only three were good enough for commercial tests.

Our eleven best hybrids had the following advantages over commercial varieties: stronger vegetative development, higher yielding capacity and higher early yield; two of these hybrids moreover had a better disease resistance.

Is it safe to conclude from the above results that commercial growing of hybrids in the Netherlands will always give better financial results?

To answer this, it is necessary to take the course of market prices into consideration. Figure 7 shows the fluctuation in the monthly supply and average auction price in the Netherlands during the years 1954, 1955 and 1956. From April to July the price falls sharply; usually it gradually descends during July and August and is low until September. In some years, e.g. 1956, the price stays at the same level during July and August. After September the price gradually rises again.

It is interesting to compare figure 7 with the incremental yield graphs of our hybrids (Figs 2, 3, 4, 5 and 6). Reviewing figures 2, 4, 5 and 6 one should keep in mind that under commercial conditions the yield curves would be shifted about two weeks to the left. Figure 3 is directly applicable to commercial conditions. 
Fig. 7. Data Received from "Centraal bureau VAN DE TUINBOUWVEILINGEN IN NEDERLAND"

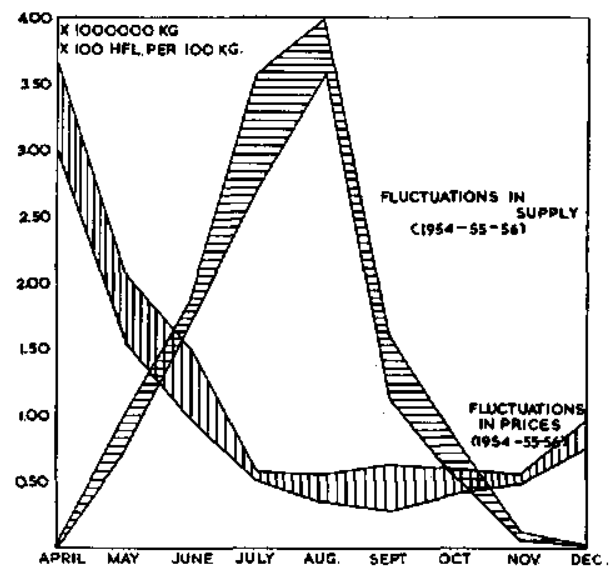

From figures 2, 3, 4, 5 and 6 - considering the shifting of dates - it may be concluded that the higher early yield of our hybrids grown in a coldhouse will be obtained between the middle of July and the beginning of August. This means that a higher early yield, in our trials varying from a few hundred grams to 1 kilogram per plant, in some years (1956) gives no financial advantages at all. In other years, for instance 1954 and 1955 , the financial advantage will be relatively small.

Generally we may conclude that the advantages of good hybrids, if grown in Dutch coldhouses, only result in a relatively small financial advantage, due to the typical course of the prices during the season. On the other hand we may expect that on account of the much higher prices before the month of July a higher early yield of hybrids, grown in heated glasshouses, will result in a much greater commercial advantage. Unfortunately, due to the absence of a heated glasshouse, we were unable to confirm this experimentally.

Planting in the last week of February in heated glasshouses in the Netherlands results in the harvest being about a month earlier, compared with coldhouses. All growing conditions - except for the heating - are about the same in both types of glasshouses. So it may be expected that good hybrids will behave similarly in only slightly heated and unheated houses, with respect to higher yielding capacity and higher early yield. In this case, a higher early yield will definitely result in a remarkably higher financial profit.

Further experiments are needed to draw final conclusions on the behaviour of the hybrids grown in early heated houses. In this culture planting is carried out between the end of January and the beginning of February, when the growing conditions, especially the amount of light, are quite different from those prevailing later in the season.

Financially a higher early yield of tomatoes grown in heated glasshouses may be more profitable than a higher total yield. It is possible to obtain early hybrids with a high early yield by crossing Dutch commercial varieties with very early ripening varieties. So far it has proved impossible to combine extreme earliness with all the other desired commercial characters. To improve this it is necessary to breed better early yielding parents, with better combining ability. 


\section{J. M. ANDEWEG AND J. H. RUYTEN}

\section{SUMMARY}

From 1950 to 1956 a total number of 196 hybrids was tested in coldhouses. After continuous selection eleven commercially acceptable hybrids remained. In comparison with commercial varieties all these eleven hybrids showed the advantage of stronger vegetative development, higher yielding capacity and higher early yield; two of them moreover possessed a better disease resistance.

Generally we may conclude that the advantages of good hybrids, if grown in Dutch coldhouses, only result in a relatively small financial advantage; the higher early yield is obtained between the middle of July and the beginning of August, a period of low, nearly constant prices. On the other hand, on account of the much higher prices before the month of July a higher early yield of hybrids, grown in a heated glasshouse, will result in a much greater commercial advantage.

With hybrids, adaptation to changes in growing and market conditions can be obtained rapidly. Good examples are leaf mould resistant hybrids of Ailsa Craig strains $\times$ Vagabond and a better nematode resistant hybrid of Ailsa Craig $\times$ H.E.S. 4245 .

Crosses of Dutch commercial varieties with parents originating from countries with a warmer climate, gave disappointing results under unfavourable weather conditions.

In order to obtain outstanding early hybrids it is necessary to breed better early yielding parents, with good combining ability.

\section{SAMENVATTING}

\section{Zevenjarige ervaring met tomaten-hybriden}

Gedurende de jaren $1950 \mathrm{t} / \mathrm{m} 1956$ werden in totaal 196 hybriden beproefd bij de teelt in onverwarmde warenhuizen. Na voortdurende selectie bleven in totaal elf voor de praktijk acceptabele $F_{1}$-combinaties over. Deze elf hybriden vertoonden ten opzichte van de gewone rassen een sterkere vegetatieve groei, een hoger opbrengstvermogen en een grotere vroege opbrengst; twee van deze hybriden hadden bovendien een betere ziekteresistentie.

Bij de teelt in onverwarmde warenhuizen in Nederland blijken de genoemde voordelen van hybriden meestal slechts een betrekkelijk gering financieel voordeel op te leveren, daar grotere vroege opbrengst tussen half juli en begin augustus verkregen wordt en de prijs na de maand juni in de regel reeds tot een laag niveau gedaald is.

Verwacht mag worden, dat bij teelt in verwarmde warenhuizen de met hybriden te bereiken grotere vroege opbrengst wèl zal resulteren in een belangrijk groter financieel voordeel, door de veel hogere prijzen vroeger in het jaar.

Met hybriden is een snelle aanpassing aan gewijzigde teelt- en markteisen mogelijk. Voorbeelden hiervan zijn een hybride met resistentie tegen bladvlekkenziekte uit Ailsa Craig $\times$ Vagabond en een hybride met grotere resistentie tegen wortelknobbelaaltjes uit Ailsa Craig $\times$ H.E.S. 4245 .

Onder minder gunstige weersomstandigheden gaven hybriden waarbij ouderrassen uit landen met een warmer klimaat gebruikt werden teleurstellende resultaten. Om een maximaal effect met $F_{1}$ 's te bereiken is het noodzakelijk betere, vroegrijpende ouders te kweken, met een goede "combining ability". 


\section{EXPERIENCE WITH HYBRID TOMATOES}

\section{LITERATURE CITED}

1. Ashton, T., The use of heterosis in the production of agricultural and horticultural crops. Cambridge, Commonwealth Agricultural Bureau. 1946.

2. BuRdicK, A. B., Genetics of heterosis for earliness in the tomato. Genetics 39 (1954): 488-505.

3. Daskaloff, Chr., Die Heterosis und ihre Ausnützung im Gemüsebau. Die Deutsche Landwirtschaft 6 (1955): 384-389.

4. GILEs, J. E., Desirable combinations of characters in $F_{1}$ hybrid tomatoes for the glasshouse. J, Aust. Inst. Agr. Sci. 20 (1954): 238-242.

5. Haskell, G. and Brown, A. G., Hybrid vigour in cultivated tomatoes. Euphytica 4 (1955): $147-162$.

6. Hoffman, I. C., First generation tomato hybrids for greenhouse use. 32 nd Proc. Ohio Veg. Potato Gr. Ass. (1947): 148-153.

7. KERR, E. A., Breeding for resistance to leaf mold in greenhouse tomatoes. Hort. Exp. Station and Products Lab. Report for 1953 and 1954: 76-80.

8. MATHER, K. and CRANE, M. B., The yields of tomato varieties in an outdoor trial. J. Roy. Hort. Soc. 67 (1942): 92-94.

9. Podesva, J., (The results of experiments on producing heterosis in tomatoes grown for indoor and outdoor use). Horn. Vysoké Skol. Zemed. Les. Brno. no. 2 (1954): 11-18.

10. Walkof, Ch. and Nuttall, V. W., Hybrid vegetables for short-season gardens. Experimental Station, Morden, Manitoba. Publ. 947 (1955), p.p. 7. 